\title{
Los Palacios Civiles de la calle Gravina de Alicante: las piedras utilizadas en su construcción y su alteración por sales
}

\author{
The Civil Palaces in Gravina street, Alicante: building stones \\ and salt weathering
}

\begin{abstract}
M. LOUIS( ${ }^{(*)}$; M. A.GARCÍA delCURA("*); Y.SPAIRANI ${ }^{(\cdots)}$; D. de BLAS $\left({ }^{(\cdots)}\right.$ (")Dr. Arquitecto, Dpto. de Construcciones Arquitectónicas. Univ. de Alicante, Laboratorio de Petrología Aplicada, Unidad Asociada UA-CSIC (") Dra. en Geología. Inst ${ }^{\circ}$ de Geología Económica CSIC-UCM, Laboratorio de Petrología Aplicada, Unidad Asociada UA-CSIC ('“) Arquitecto Técnico, Dpto. de Construcciones Arquitectónicas. Univ. de Alicante
\end{abstract}

Fecha de recepción: 18-VIII-00

Fecha de aceptación: 26-I-01

ESPAÑA

\section{RESUMEN}

En este trabajo se realiza un estudio de la arquitectura, construcción y materiales utilizados en los Palacios Civiles del siglo XVIII, situados en la calle Gravina (actual sede del Museo Provincial de Bellas Artes de Alicante).

Las rocas utilizadas en la construcción original asi como las utilizadas en sustituciones posteriores en estos Palacios Civiles son calizas bioclásticas y/o calcarenitas (Piedra de San Julián y Piedra Bateig). También están presentes la Piedra de Campello y otras calizas.

La disgregación granular y la erosión alveolar son las formas de alteración más abundantes en el exterior de estos Palacios Civiles. Estos tipos de alteración están relacionados con la cristalización de sales, procedentes del spray marino y/o de las aguas capilares del suelo. $\mathrm{El} \mathrm{NaCl}$ es la sal más abundante debido a la proximidad de la costa.

La halita también está presente en eflorescencias de interiores. En la cara interna del aplacado de exteriores hemos encontrado eflorescencias de yeso y de ettringita. El aplacado se ha destruido y ha sido reemplazado en la última restauración.

\section{SUMMARY}

This paper presents a study into the architecture and construction of the $18^{\text {th }}$ Century Civil Palaces located in Gravina street (Provincial Museum of Fine Arts of Alicante), the building stones used and the mineral related decay' processes that these materials have suffered.

The original building stones and other stones used in subsequent restorations in these Civil Palaces are bioclastic limestones and/or calcarenites (San Julian Stone and Bateig Stone). Campello stone and other limestones are also present.

Granular disintegration and alveolar weathering are the main forms of deterioration developed on the exterior of these Civil Palaces. These stone decay types are related to salt crystallisation, caused by sea spray salts and/or soil capillary waters. Halite is the most common salt found, probably due to the buildings' proximity to the coast.

The halite is also present in indoor efflorescences. Gypsum is present in some efflorescences and ettringite on the inner face of the outdoor cladding stone. The cladding has been destroyed and replaced in the last restoration process.

\section{INTRODUCCIÓN}

Esta publicación presenta un detallado estudio de diferentes variedades líticas usadas en la construcción durante el siglo XVIII de los Palacios Civiles situados

\section{INTRODUCTION}

This paper presents a detailed study into the different lythic varieties used in the construction of the $18^{\text {th }}$ Century Civil Palaces located in Gravina street of the city of Alicante (Spain), which are being 
en la calle Gravina de la ciudad de Alicante (España), que han sido restaurados para su uso como museos.

El auge económico por el comercio marítimo dio lugar, en Alicante, a una seric de construcciones civiles destinadas a residencia de los comerciantes que siguen unas pautas arquitectónicas comunes y que hoy en día llamamos las Casas-Palacio del XVIII, de las cuales quedan cerca de una docena de ejemplos, algunas de ellas con reformas importantes y cambios de uso pero recuperadas, otras en estado ruinoso y cjemplos de reciente desaparición o de los que apenas se han conservado restos o partes de las fachadas. Estas casas estaban realizadas, todas ellas, en piedra vista, dándoles cierto carácter de fortaleza, debido a los continuos ataques de los piratas berberiscos que sufría la ciudad por aquel entonces (1).

Los edificios que son objeto de estudio en el presente trabajo se sitúan en la parte baja de la ciudad pero cerca de la iglesia de Santa María, formando parte de la trama urbana planificada en el siglo XVI y que supuso una ampliación de las murallas hacia el mar, es decir, extramuros de la ciudad medieval y a muy poca altura sobre el nivel freático. En cl plano realizado en 1751 por Estevan de Panon (Figura 1) se observan las parcelas que ocuparían posteriormente, aunque la alineación de la calle Gravina se modificó al trazarse en paralelo a Villavieja y Jorge Juan. Podemos fechar por tanto la construcción de los edificios en cuestión entre los años 1770-1780.

Respecto al clima de Alicante, el Servicio Meteorológico Nacional registró los siguientes datos para el periodo 1961-1990: temperatura media mensual $17,8^{\circ} \mathrm{C}$, temperatura máxima media $23,4^{\circ} \mathrm{C}$ y temperatura mínima media $12,3^{\circ} \mathrm{C}$, sin dias de heladas, precipitación media anual de $357 \mathrm{~mm}$, humedad relativa media $66 \%$. street of the city of Alicante (Spain), which are being restored for use as museums.

The economic boom in Alicante generated by maritime trade led to the construction of a series of civil buildings destined for use as merchants' residences. These buildings were constructed in accordance with the usual architectonic guidelines and are today known as the $18^{\text {th }}$ Century Palace-Houses. There still remain a dozen examples of these houses, some of which have been saved after having suffered significant deterioration and/or changes in use. Others are in a state of ruin or have recently been lost or their remains or façade parts have hardly lasted out. These houses were all made of stone, which lent them a fortress-like appearance. They were built in this way due to the continuous Berber pirate attacks which the city suffered at that time (I).

The buildings analysed in this study are located in the lower side of the city near the Santa Maria church and are part of the urban planning of the $18^{\text {th }}$ Century which involved extending the city walls to the sea, beyond the medieval city and slightly above the sea level. In the street map made in 1751 by Estevan de Panon (Figure 1), we can see the plots which the buildings later occupied, although Gravina Street was modified in order to make it parallel to Villavieja and Jorge Juan Streets. Therefore, we can date the construction of these buildings between 1770 and 1780.

As regards the climate of Alicante, the Spanish National Meteorological Institute recorded the following data for the period 1961-1990: average monthly temperature $17.8^{\circ} \mathrm{C}$, maximum average temperature $23.4{ }^{\circ} \mathrm{C}$ and minimum average temperature $12.3^{\circ} \mathrm{C}$, with no days below $0{ }^{\circ} \mathrm{C}$, annual average rainfall $357 \mathrm{~mm}$, average relative humidity $66 \%$.

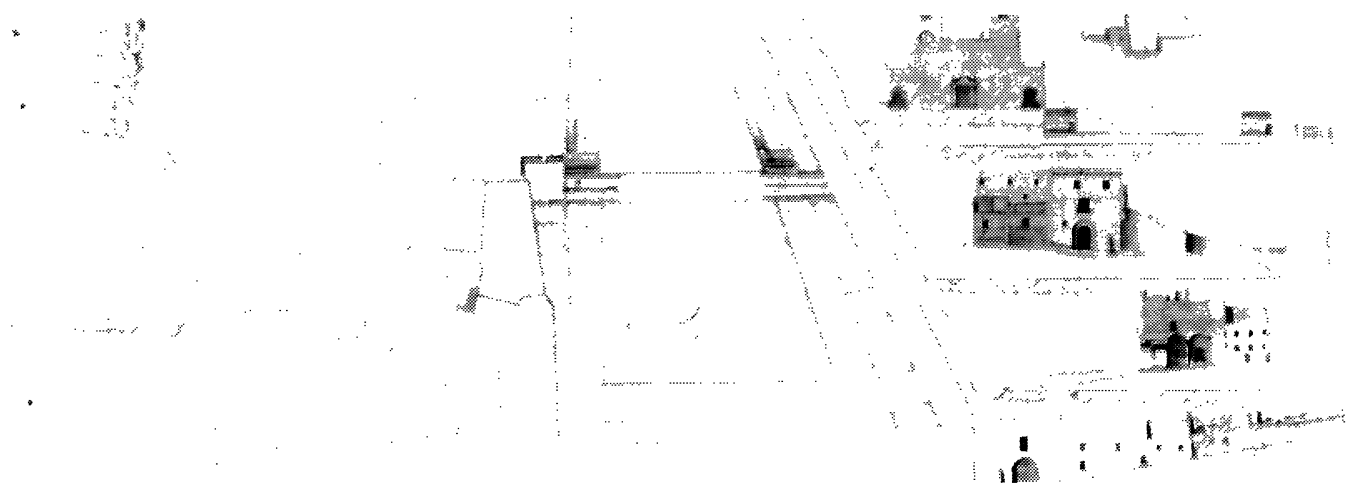

Figura 1.- Mapa callejero de Alicante de 1751 por Estevan de Panon.

Figure 1.- Street map of Alicante from 1751 by Estevan de Panon. 


\section{Descripción Arquitectónica}

La configuración urbana y arquitectónica del Alicante del siglo XVIII viene determinada por dos acontecimientos bélicos, el bombardeo de la ciudad por la armada francesa en 1691 y la Guerra de Sucesión, que ocasionaron la desaparición de gran parte de las edificaciones existentes.

La recuperación posterior supuso más una reconstrucción que un nuevo concepto urbanístico de la ciudad, ya que manticne su esquema original, dentro del recinto amurallado medieval.

El diseño y construcción de edificios civiles del siglo XVIII en Alicante se caracterizan por sus formas austeras de apariencia de fortaleza. Además los exteriores de estos edificios no están profusamente decorados, como era habitual en la época; ambas características probablemente sean resultado de los frecuentes ataques de piratas.

Los palacios situados en la calle Gravina de Alicante son dos edificios adosados entre sí, ocupando más de media manzana en el que hemos denominado ensanche del XVI. A primera vista lo que nos encontramos cs una fachada principal, común a ambos edificios, realizada en sillería vista y otras dos laterales, con un tratamiento secundario, que se terminan con revestimiento de mortero de cal, hoy cubierto por diversas capas de pintura. A pesar de formar esquina ésta no se enfatiza como tal, critcrio arquitectónico común en los edificios de la época.

Es, por tanto, en la fachada principal (Figura 2a y $2 b$ ) donde se reconocen todos los elementos arquitectónicos de relieve, siguiendo pautas de simetría en su

\section{Architectonic Description}

The urban and architectonic layout of Alicante in the $18^{\text {th }}$ Century was determined by two warlike events: the bombardment by the French armada in 1691 and the War of Succession, which led to the destruction of a large number of the then existing monuments.

Subsequent recovery involved reconstruction rather than a new urban model, as the original layout was conserved within the medieval walls and new stage constructions were integrated into this area.

The design and construction of civil buildings in the $18^{\text {th }}$ century in Alicante is characterised by their austere fortress-like appearance. Furthermore, the exteriors of these buildings are not extravagantly decorated, as was normal in that time, probably as a result of the frequently pirate attacks.

The palaces located in Gravina street, Alicante, are two connected buildings, and occupy more than half a block in what we have named the $16^{\text {th }}$ Century extension. First, we find the main façade which is shared by both buildings and is made of uncovered masonry. The other two side façades have undergone a secondary treatment. The fact that the building is situated on a corner is not surprising as it was a standard feature common to buildings of that period.

Therefore, it is upon the main façade (Figure $2 a$ and 2b) that all the significant architectonic elements are to be found, in accordance with symmetry guide lines, with both a horizontal and vertical recess
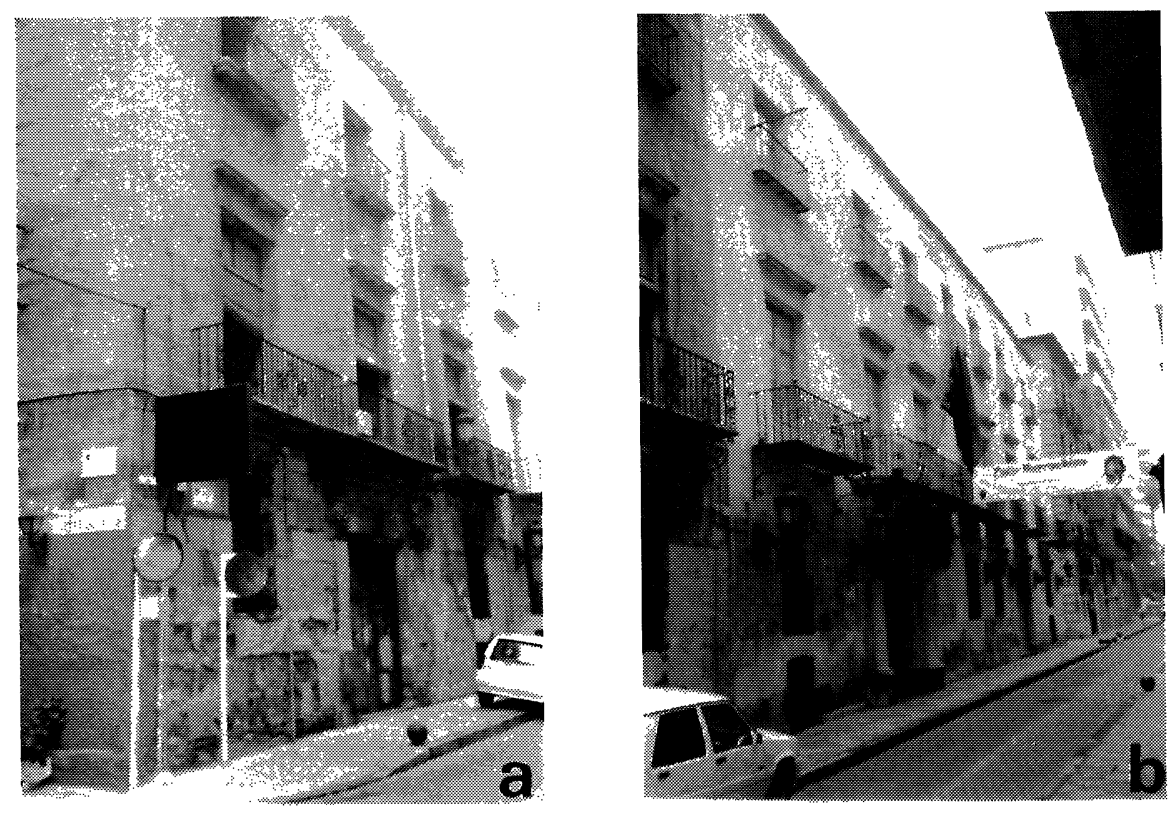

Figura 2.- Fachada principal de los Palacios Civiles de la calle Gravina: a) $\left.\mathrm{n}^{\circ} 11, \mathrm{~b}\right) \mathrm{n}^{\circ} 13$.

Figure 2.- Main façade of Civil Palaces in Gravina street: a) $n^{\prime \prime} 11$, b) $n^{\circ} 13$. 
composición, con una ordenación de huecos tanto vertical como horizontal. A lo ancho se distribuyen diez huecos iguales con entrepaños que sufren algunas variaciones en su dimensión y en altura se alinean y jerarquizan por plantas. En el primer piso son de mayor tamaño, con guardapolvos y grandes bandejas de balcones que son las clásicas del XVIII, con suelo de tablas de madera sujeto por jabalcones metálicos. En el segundo piso los huecos son más pequeños y no disponen de guardapolvo. Aunque tienen balcones las bandejas son de piedra y mucho menores en tamaño y vuelo, sistema que se adoptará como definitivo en la arquitectura del XIX. En planta baja, el segundo edificio, actual Archivo Provincial, presenta dos líneas de arcos carpaneles apoyados en pilastras y en el otro sólo existe un arco de medio punto.

Los edificios debieron construirse por separado aunque, siguiendo criterios fachadistas, se realizaron con idéntico tratamiento exterior, diferenciándose tan sólo en los pórticos de acceso, existiendo un total de tres, siendo de dintel recto el del primer palacio y de medio punto los del segundo (Figura 3).

\section{Estudio Constructivo}

La cimentación, sobre material limoso y escombros mezclados con arenas y gravas de playa, está realizada en el primer plano con mampuestos de pequeño tamaño, puesto que apenas supcran los $10 \mathrm{~cm}$ de diámetro, con un espesor de zanja igual a los muros y una profundidad de $50 \mathrm{~cm}$, apareciendo, entonces, una losa de piedra.

Los muros están realizados con dos hojas en la fachada principal, siendo de una hoja tanto en la lateral como en medianerías e interiores, variando su espesor en función de si soportan o no cargas.

La fachada principal está formada por una hoja externa de sillería vista de $30 \mathrm{~cm}$ de espesor y otra hoja trasdosada de mampostería revestida con mortero de cal dando un total de $80 \mathrm{~cm}$, que se reducen a $65 \mathrm{~cm}$ en la primera planta y a $50 \mathrm{~cm}$ en la segunda. La lateral de calle Bendicho es toda de mampostería salvo en la esquina, aunque los sillares están ocultos bajo la pintura.

La medianera posterior, que fue fachada al patio trasero tiene también $80 \mathrm{~cm}$ en planta baja, reduciéndose hasta los $50 \mathrm{~cm}$ en los pisos altos como la fachada principal. La otra medianera lateral está parcialmente en ruinas, en parte desaparecida en el patio y con grandes grietas en la zona de contacto con el edificio del Archivo Provincial.

Los muros interiores son de menor espesor, $70 \mathrm{~cm}$ los dos primeros y $65 \mathrm{~cm}$ cl tercero de la escalcra, reduciéndose a $45-50 \mathrm{~cm}$ en primera planta y a 40-45 en la segunda. arrangement. Ten recesses are distributed across the width with some variations in the dimensions of the spaces between them. They are aligned vertically and dealt with according to a hierarchy, which is governed by the floor they are to be found on. On the first floor they are larger, with a ledge and large classical $18^{\text {th }}$ Century balconies with a wooden roof supported by metallic corbels. On the second floor, the recesses are smaller with no dust coverings. Although they do also have balconies, they are much smaller in size and overhang, and the roof is made of stone. This system was to be adopted as definitive in $19^{\text {th }}$ Century architecture. On the ground floor, the second building, which is today the Provincial Archive, has two carpanel arch lines built on pilasters supported, and in the other building there is just a half point arch.

Although the buildings were built separately, work was carried out with the same exterior treatment in accordance with façade criteria, varying only in the gateway entrances. There were a total of three gateway entrances, the first palace had one with a straight threshold and the second palace had two with half-point threshold (Figure 3).

\section{Construction Study}

The foundations, over mud and rubbles mixing with sands and gravel beach, are made of tiny rough stones (approximately $10 \mathrm{~cm}$ in diameter), with a trench as wide as the walls and a depth of $50 \mathrm{~cm}$ which then reveals a stone.

Walls are two-leafed on the main façade, and single-leafed both on the side façade and on party walls and interior walls. The thickness of these walls depends on whether they are support walls or not.

The main façade is formed by an exterior uncovered masonry leaf which is $30 \mathrm{~cm}$ thick and another interior rough stone leaf covered with lime. The unit is $80 \mathrm{~cm}$ thick, but reduces to $65 \mathrm{~cm}$ on the first floor and to $50 \mathrm{~cm}$ on the second floor. The side façade which looks onto Bendicho Street is made in rough stone except on the corner, although the stone blocks are hidden under a cover of paint.

The back party wall, which used to be a façade to the rear cour is also $80 \mathrm{~cm}$ thick on the ground floor, and narrows to $50 \mathrm{~cm} \mathrm{c}$ the upper floors in the same way as the main façade. The other side party wall is practically in ruins, and in part totally destroyed on the courtyard, and has large cracks where it join the Provincial Archive building.

The interior walls are narrower, the first two measuring $70 \mathrm{~cm}$ and the third, on the stairs, $65 \mathrm{~cm}$, and narrowing further to $40-50 \mathrm{~cm}$ on the first floor and to 40-45 cm on the second floor 
Los arcos del zaguán tienen una base de sillar y el resto está revestido, aunque es muy posible que, al menos el perfil del arco, sea de sillería, la cual, posteriormente, fue ocultada (Figura 4). Aparecen chapados de ladrillo macizo usados como refuerzo y de ladrillo hueco más recientes, posiblemente para tapar los daños causados por la humedad.

Los huecos son todos adintelados, incluso el pórtico principal, realizados con la misma piedra formando dovelas que apenas presentan pérdidas de mortero en rejuntados y ninguna grieta visible. Los balcones con bandejas de piedra en segunda planta están en un estado aceptable aunque aparecen algunas piezas rotas o agrietadas.

Se observan numerosas reparaciones y aplacados, parcheados, etc... en toda la parte baja de la fachada principal, donde los muros han sido afectados por la humedad de capilaridad provocando importantes alveolizaciones y arenizaciones de la piedra ( 2 y 3$)$. Se han utilizado para ello placas de piedra de Bateig, de $3 \mathrm{~cm}$ de espesor, cogidas con escarpias y yeso, rellenando el intradós con mortero de cemento (Figura 5). También hay rejuntados y parcheados realizados con mortero de cemento blanco o gris muy desafortunados. El ensuciamiento se detecta en zonas resguardadas como cornisas y bajos de balcones, sin llegar a niveles importantes.

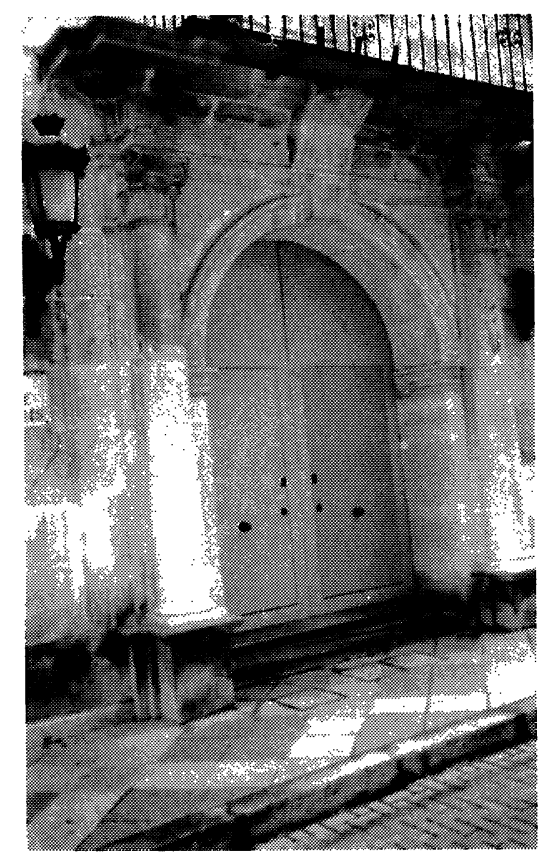

Figura 3.- Puerta principal de acceso al Palacio Civil de la calle Gravina $n^{\circ} 13$.

Figure 3.- Main entrance gateway to civil Palace in Gravina street $n^{\circ} 13$.
The arches in the hallway have a stone block base, and the rest is covered, though it is possible that at least the arch profile was made with stone blocks and later covered (Figure 4). Solid brick coverings are used as reinforcement and also more recent hollow brick coverings, which were possibly installed to hide damage caused by damp.

All of the recesses have a straight upper lintel, including the main portico, which is made of the same stone, and form keystones. There are practically no mortar losses at the joints, and no visible cracks. The stone-floored balconies on the second floor are in a satisfactory condition although there are some broken or cracked pieces.

There are numerous reparations and plaque coverings, patching, etc. along the entire lower part of the main façade, where the walls have been affected by capillary moisture which has generated alveolar weathering and granular disintegration (2 y 3). For this reason, $3 \mathrm{~cm}$ thick Bateig stone plaques have been used, together with tenterhooks and plaster, and the inner surface filled with cement mortar (Figure 5). There is also very unfortunate grey or white cement patching. Slight staining is detected in protected zones such as the cornices and the areas under the balconies.

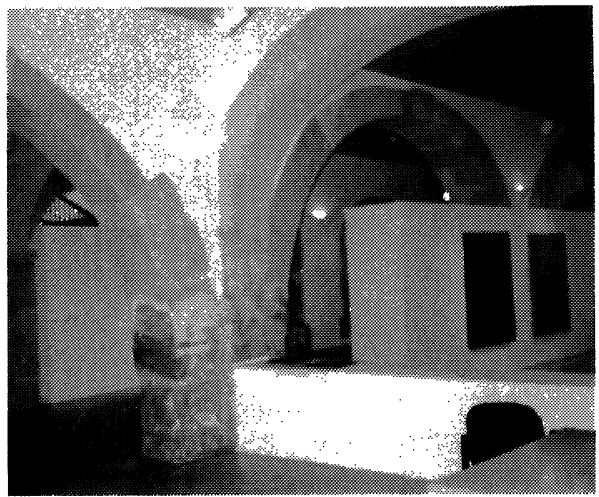

Figura 4.- Eflorescencias de halita en los arcos del zaguán del Palacio de Gravina $n^{\circ} 13$.

Figure 4.- Halite efflorescences on arches in the hallway stones of Gravina Palace $n^{\prime \prime} 13$. 

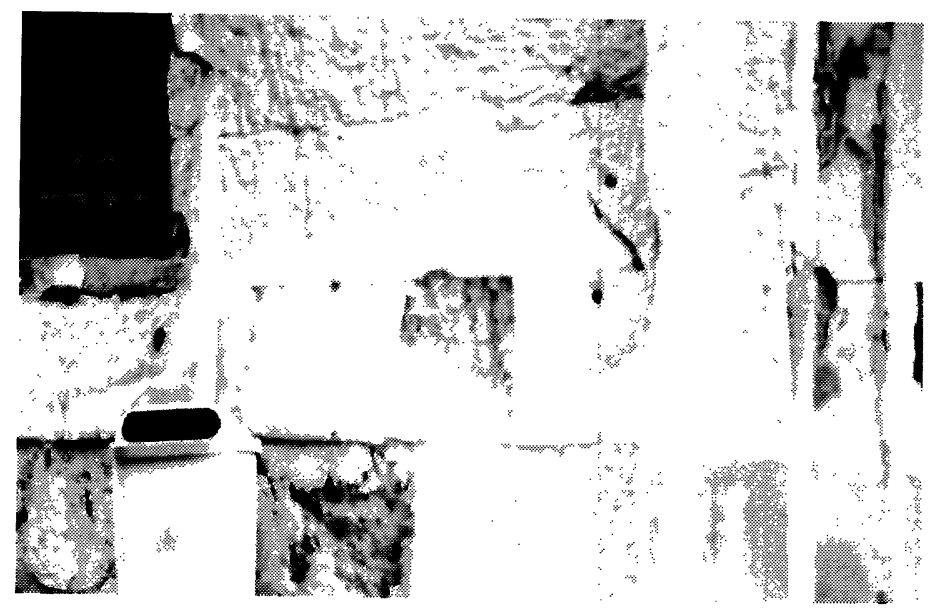

Figura 5.- Alteración del aplacado.

Figure 5.- Cladding decay:

El resto de los muros tiene un alto contenido de humedad incluso en mediciones realizadas en julio y agosto, con índices de 40-60 en cl humidímetro. No se observan, sin embargo, pérdidas de material y la verticalidad es correcta.

En el pavimento del zaguán lo más interesante a reseñar son las grandes baldosas de piedra de San Julián aparecidas bajo un terrazo colocado en los años 50. Estas baldosas eran el pavimento clásico en este tipo de Casas-Palacio.

El Archivo fue intervenido en 1980, sustituyéndose los forjados y reforzando la cimentación con micropilotes. También se sustituyeron sillares y se realizó un tratamiento contra la humedad. El otro palacio, en mucho peor estado, fue rechapado hacia 1970 en todo su zócalo con muy poca fortuna, utilizando Piedra de Bateig distinta a la original que se ha degradado rápidamente. Algunas bandejas de balcones han sido sustituidas por rasillas revestidas con mortero y azulejos. Sin embargo, la mayor reforma tuvo lugar a finales del s. XIX al ser transformado en el hotel Miramar, incluyendo nuevos forjados, cambiando la distribución y colocando falsos techos, lo que ha dado origen a grietas.

Los materiales que forman los elementos constructivos son de tres tipos: piedra caliza, micrita arenosa bastante homogénea, en interiores en la base de pilastras, parcialmente sustituida por Piedra de Campello en la intervención de 1980 y Piedra de San Julián en el resto de elementos constructivos, sustituida en algunas dovelas y aplacados de exteriores por Piedra de Bateig. Los morteros son todos de cal.
The rest of the walls have a high moisture content even in measurements taken in July-August, with moisture meter indexes of about 40-60. However, there are no material losses and verticality is aligned.

As regards the hallway flooring, the most interesting features are the large San Julian paving stones discovered under the flooring installed in the 50's. This was the classic flooring used in this type of Palace Houses.

Work was carried out on the Archive building in 1980, when the party floors were replaced and the foundations strengthened with micropiles. The stone blocks were also replaced and an anti-damp treatment was applied although, as we shall see later, the salts from both the sea and soil have damaged its walls and pilaster bases once again. The other palace, which is in much worse condition, had its socle re-covered in about 1970. Unfortunately, this process was not successful as Bateig Stone different from the original was used and it decayed rapidly. However, the most important alterations took place in the later $19^{\text {th }}$ Century, when the building was transformed into the Miramar hotel. These alterations included the installation of new party floors and plaster ceilings, as well as changing the actual interior layout of the building, creating cracks.

There are three types of materials used in the construction of this building: a highly homogeneous limestone on the pilaster bases, San Julian Stone on the rest of the building and Bateig Stone in renovated arch pieces and outdoor claddings. All the mortars are of lime. 


\section{METODOLOGÍA}

Las rocas de construcción originales y las utilizadas en posteriores restauraciones han sido muestreadas y preparadas en sección delgada después de haber sido impregnadas con resina coloreada en una cámara de vacío. Las superficies de fractura de estas rocas han sido estudiadas por microscopía electrónica de barrido (MEB) en modo de electrones secundarios (ES).

Las caras interna y externa de los aplacados y de los fragmentos de roca originados por descamación han sido también estudiadas por microscopía electrónica de barrido.

Las técnicas petrográficas y mineralógicas utilizadas para clasificar las rocas han sido: microscopía óptica de luz transmitida (MOLT) (microscopio Zeiss, Assioscop); microscopía electrónica de barrido (MEB) habiéndose utilizado un microscopio JEOL JSM-840, trabajando en modo de electrones secundarios con $20 \mathrm{kV}$. Este microscopio cuenta con equipo de análisis por energía dispersiva de rayos $\mathrm{X}$ (EDX). Las muestras fueron cubiertas con una fina capa de oro en un evaporador de alto vacío SCD 004.

La composición mineralógica de rocas (\% de calcita) y eflorescencias se ha determinado por difracción de rayos $\mathrm{X}$, con cuarzo como patrón interno; fue realizada con un difractómetro Philips 1840.

Las propiedades físicas de las rocas (Piedra de Campello y Bateig) se han determinado según las siguientes normas:

El peso específico y la absorción de agua-Norma UNE 22$182-86$

La resistencia a compresión-Norma UNE 22-185-85, La resistencia a flexión-Norma UNE 22-186

La resistencia al choque-Norma UNE 22-189

La resistencia al desgaste-prEN-1339/99 (Pronorma europea)

La determinación de los porcentajes de humedad se ha realizado con el termohigrómetro "Protimeter".

\section{RESULTADOS}

En las catas realizadas en el suelo se han encontrado escombros mezclados con arenas y gravas rodadas de playa hasta llegar a un material homogéneo de tipo limoso. Hay abundantes fragmentos de piedra, ladrillos, yeso e incluso morteros de cemento, lo que indica que se trata de rellenos bastante recientes.

El grado de humedad del terreno cs elevado, con un valor del $32 \%$ y el contenido de sales bajo, pero se incrementa a

\section{METHODOLOGY}

The original building stones and the stones used in subsequent restorations have been sampled and prepared in the same way as thin layers after being injected with resin in a vacuum. Broken surfaces of these rocks are studied by a scanning electron microscope (SEM) in secondary electrons mode (SE).

Inner and outer surfaces of the claddings and flake rock fragments are also studied by the scanning electron microscope.

The petrographic and mineralogical techniques used to classify these building stones were: transmitted light microscopy (TLM) (Zeiss, Assioskop), scanning electron microscope (SEM): using a JEOL JSM-840 microscope working in secondary electron mode with $20 \mathrm{kV}$. This microscope has an analysis equipment of dispersive energy of $X$-ray (EDX). The samples were covered with a thin layer of gold in a high vacuum evaporation SCD 004.

The mineralogical composition of stones (\% of calcite) and efflorescences was determined by X-ray diffraction, using quartz as internal standard, in a Philips 1840 difractometer.

Physical properties of the stones (Campello and Bateig stone) were determined by the following norms:

Density and water absorption-Norm UNE 22-

182-86

Compressive strength-Norm UNE 22-185-85,

Flexural strength-Norm UNE 22-186

Impact resistance-Norm UNE 22-189

Abrasion resistance-prEN-1339/99 (europeen

Pronorm)

Humidity was determined with the termohigrometer "Protimeter".

\section{RESULTS}

From the prospecting done in the soil rubbles mixing with sands and gravel beach are found, until a homogeneous mud, there are plenty of fragments of rock, bricks, gypsum and even cement mortar, which indicates that these are quite recent fillings.

There is a high percentage of moisture in the terrain $(32 \%)$ and the salt content is low, but both increase 
mayor profundidad, sin llegar a contenidos importantes, aunque la proximidad del nivel del mar hace pensar que encontraríamos mayores cantidades en niveles inferiores. El relleno de escombro ha impedido, en este caso, que las sales afecten al pavimento, aunque no a los muros que en su base se apoyan en el terreno.

El material pétreo que se encuentra en este palacio es variado, pues junto a las rocas empleadas originalmente encontramos otras utilizadas en restauraciones posteriores. Así, en basas y zócalos interiores el material pétrco original es una caliza micrítica arenosa (Figura 6a y 6b) que presenta del orden de un $30 \%$ de fracción arenosa constituida por granos de cuarzo monocristalino de angulosos a subangulosos, algunos granos de feldespatos y de sílex así como de dolomías, lutitas y algunas rocas metamórficas (metacuarcitas y pizarras). Estos detríticos presentan una moda de 0,12-0,25 mm. La calcita presenta textura porfídica, apareciendo cristales de hasta $0,3 \mathrm{~mm}$, dispersos en el seno de la micrita; tambićn contiene fantasmas de fósiles retrabajados. Esta roca presenta porosidad de hueco y algo de porosidad de vénula.

En la fachada y muros interiores originalmente se utilizó Piedra de San Julián, que es una biocalcarenita (bioesparita según Folk) cuyo tamaño de grano es variable: de arena media a arena gruesa e incluso microconglomerado ( $>2 \mathrm{~mm})$, siendo también variable su contenido en terrígenos (Figura 6c). Esta roca cstá formada básicamente por fragmentos de fósiles: briozoos, moluscos, foraminíferos y algas rojas, siendo alta su porosidad, tanto interpartícula como intrapartícula. Contiene algunos filosilicatos, siendo de destacar, por su abundancia, la glauconita. En menor cantidad ha podido observarse con el MEB la presencia de filosilicatos fibrosos: sepiolita y/o paligorskita. Algunas propiedades físicas de la Piedra de San Julián pueden verse en la Tabla 1. Su resistencia a compresión, determinada por la norma RILEM para piedras de cantera, es de 6.1 Mpa, habiéndose encontrado resistencias de hasta $15 \mathrm{Mpa}$ en el material utilizado en el Ayuntamiento de Alicante (4).

En alguna restauración en interiores, tal como puede verse en la basa restituida lateral derecha de la $2^{\mathrm{a}}$ columna, se ha utilizado una caliza fosilífera (biomicrita según Folk) (Figura 6e), identificable como Piedra de Campello, con escasos indicios de cuarzo (detrítico y autigénico) y una marcada orientación de los fósiles que define la macroestructura bandeada de la roca. Vénulas filiformes de calcita aparecen perpendiculares y oblicuas a dicha estructura. En el conjunto de fósiles predominan los foraminíferos, especialmente los nummulítidos, enteros y fragmentados; también hay fragmentos de moluscos, briozoos y algas rojas. with the depth, although never reaching substantial amounts. However, proximity to the sea level tends to suggest that higher quantities could be found at deeper levels. In this case, the filling has prevented the salts from damaging the flooring but not the walls, which are supported by the soil at their base.

A variety of stone materials were found within these palaces, since, in addition to the rocks used originally, others have been found which were used in subsequent restorations. At first the stones used were sandy limestones and San Julián Stone, for substitutions Campello Stone and Bateig Stone were mainly used. Then, in bases and inner socles the original stone material is a sandy micritic limestone (Figure $6 a$ and $6 b$ ) which contains a sandy fraction of approximately 30\% formed by monocrystalline quartz grains from angulous to subangulous, some feldspar and chert grains and dolostones, siltstone as well as some metamorphic rock (metaquartzites and slates) grains. These detritics show a mode of 0,12-0,25 $\mathrm{mm}$. The calcite contains porphyry texture, and crystals up to $0,3 \mathrm{~mm}$ scattered throughout the micrite, as well as eroded fossil ghosts. This rock has bug porosity and some vein porosity.

On the façade and the interior walls, San Julian stone was originally used, which is a biocalcarenite (biosparite according to Folk) with a variable grain size, from medium to large-size sand grains and even a microconglomerate $(>2 \mathrm{~mm})$, whose detritic mineral content is also variable (Figure 6c). This rock is formed basically by fossils, bryozoans, foraminifers, molluscs and red algae fragments, with high porosity, both in inter and intraparticles. It contains some phyllosilicates, of which the glauconite sensu lato is the most notable because of its abundance. The rock also contains sepiolite and/or palygorskite but in lesser quantities. Some physical properties of the San Julian Stone can be seen in table 1. Compressive strength, which is determined according to the RILEM norm for quarry stones, is 6,1 Mpa, however strengths of up to 14-15 MPa have been found in some materials used in the Alicante Court House (4).

In one of the restoration processes, as can be seen on the substituted right-side base of the second column, fossilliferous limestone (biomicrite according to Folk) has been used (Figure 6e). This could be Campello Stone, with quartz traces (detritic and authigenic) and where the fossil tends strongly to one direction. This determines the banded microstructure of the rock. Foraminifera predominate throughout the fossil, especially whole and fragmented nummulites, there are also molluscs, bryozoans and red algae fragments. In 

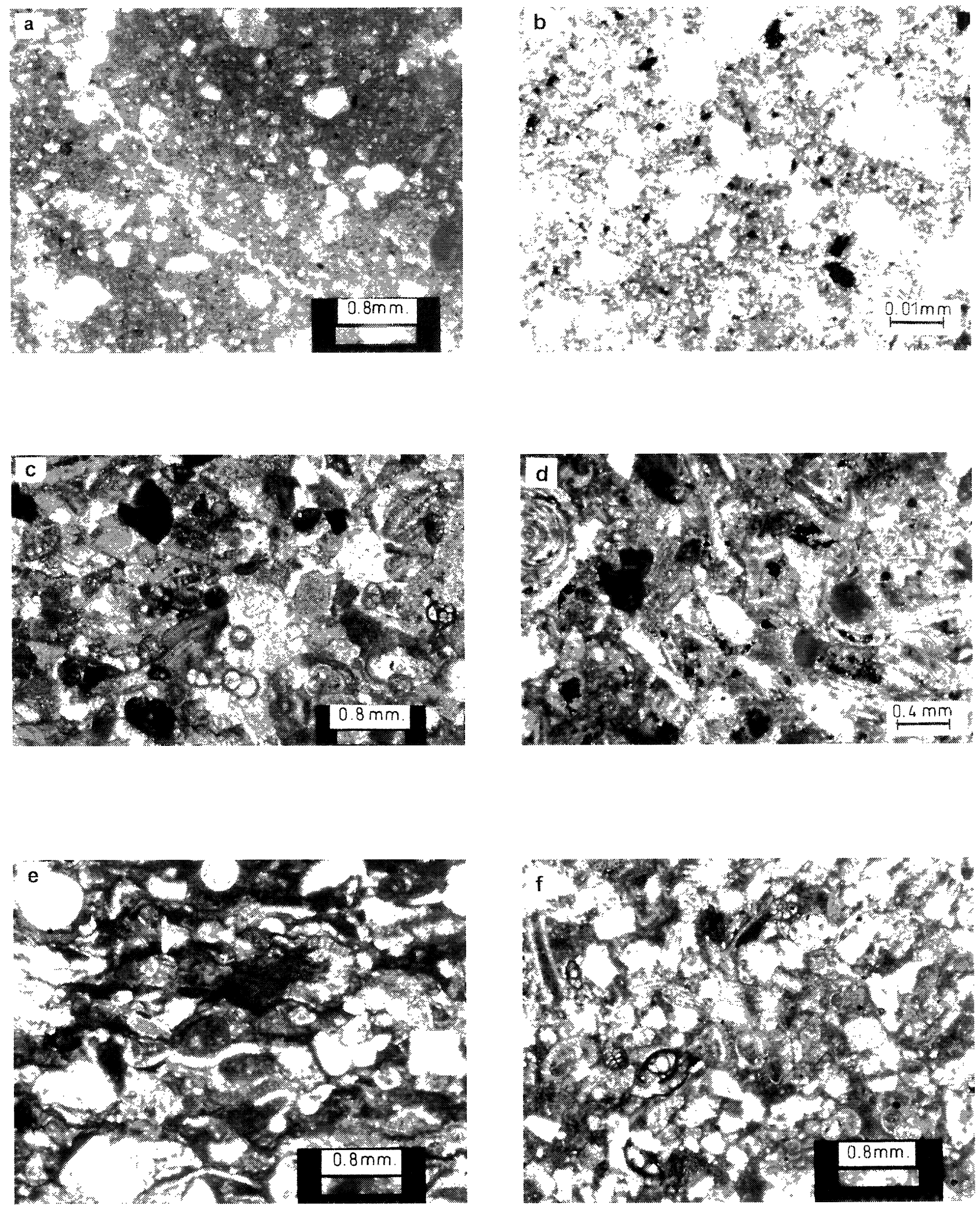

Figura 6.- Microfotografias al MOLT de las rocas de construcción de los Palacios (iviles en la calle Gravina: a) y b) micritas arenosas ) (a: con vénulas de calcita), c) y d) biocalcarenitas (Piedra de San Julián), e) calizas fosiliferas en las que los fósiles muestran orientación preferente (Piedra de (ampello), f) biomicrita arenosa (Bateig Blanco).

Figure 6.- TLM Microphotographs of building stones of (ivil Palaces in (iravina street: a) and b) sandy micrites (a: with calcite veins), c) and d) biocalcarenites (San Julian Stone), e) fossilliferous limestone where the fossil tends strongly' to one direction (Campello Stone), sandy' biomicrite (White Bateig). 
TABLA 1 (TABLE 1)

Datos de composición y algunas propiedades fisicas de la Piedra de San Julián

Data of composition and some physical properties of San Julian Stone

\begin{tabular}{||l|c|c||}
\hline $\begin{array}{l}\text { PIEDRA DE SAN JULIÁN } \\
\text { SAN JULIAN STONE }\end{array}$ & CANTERA & EDIFICIOS \\
QUUILDINGS
\end{tabular}

TABLA 2 (TABLE 2)

Datos de composición y algunas propiedades físicas de las picdras de Campcllo y Bateig

Data of composition and some physical properties of Campello and Bateig stones

\begin{tabular}{||l|c|c|c||}
\hline & $\begin{array}{c}\text { PIEDRA DE } \\
\text { CAMPELLO } \\
\text { CAMPELLO } \\
\text { STONE }\end{array}$ & $\begin{array}{c}\text { BATEIG BLANCO } \\
\text { WHITE BATEIG }\end{array}$ & $\begin{array}{c}\text { BATEIG LLANO } \\
\text { LAYER BATEIG }\end{array}$ \\
\hline $\begin{array}{l}\text { Calcita } \\
\text { Calcite } \\
\%\end{array}$ & $95-100$ & $85-90$ & $70-75$ \\
\hline $\begin{array}{l}\text { Absorción agua } \\
\text { Water absorption } \\
\%\end{array}$ & 0.59 & 5.4 & 7.6 \\
\hline $\begin{array}{l}\text { Densidad } \\
\text { Density } \\
\text { gr/cm }\end{array}$ & $2.61 \pm 0.03$ & $2.26 \pm 0.03$ & $2.13 \pm 0.01$ \\
\hline $\begin{array}{l}\text { Resistencia compresión } \\
\text { Compressive strength } \\
\text { Mpa }\end{array}$ & $86.7 \pm 9.92$ & $34.3 \pm 4.4$ & $24.1 \pm 1.7$ \\
\hline $\begin{array}{l}\text { Resistencia a flexión } \\
\text { Flexural strength } \\
\text { Mpa }\end{array}$ & $7.4 \pm 0.59$ & $11.1 \pm 1.3$ & $10.5 \pm 1.7$ \\
\hline $\begin{array}{l}\text { Resistencia al choque } \\
\text { lmpact resistance } \\
\text { cm }\end{array}$ & 40 & 20 & 19 \\
\hline $\begin{array}{l}\text { Resistencia al desgaste } \\
\text { abrasion resistance } \\
\text { mm }\end{array}$ & $20 \pm 0.23$ & $21.22 \pm 1.12$ & $20.36 \pm 1.37$ \\
\hline
\end{tabular}


Pequeñas masas de óxidos aparecen en esta roca cuyas propiedades fisicas pueden verse en la Tabla 2.

Como material de restauración en interiores también se ha utilizado una micrita con estructuras algáceas, abundante porosidad de hueco y bioturbaciones, posibles fantasmas de charáceas y escasos indicios de cuarzo de tamaño aleurítico.

La calcarenita del tipo Piedra de San Julián no es homogénea ya que la utilizada presuntamente en la obra original, concretamente en la jamba de la pucrta de Gravina 11 , presenta unos rasgos petrográficos que muestran variaciones respecto a los rasgos más característicos de la que se puede observar en los frentes abandonados de cantera: contiene del orden de un $20 \%$ de terrígenos (cuarzo, feldespato y algo de silex), un 5\% de glauconita y un porcentaje similar de dolomita. Los terrígenos presentan una moda de 0,12$0,25 \mathrm{~mm}$, siendo los restos fósiles (foraminíferos y fragmentos de moluscos, equinodermos y briozoos) ligeramente mayores. En la pasta hay un claro predominio de micrita y es abundante la porosidad inter c intrapartícular (Figura 6d).

En sucesivas reformas se ha utilizado Piedra de Batcig, especialmente para realizar aplacados de exteriores (Figura 6f), ya que la Piedra de San Julián cs un material no comercializado en épocas recientes. La Piedra de Bateig presenta diferentes variedades tanto en cuanto a su composición mineralógica como textural, experimentando sus propiedades físicas algunas variaciones en función de dicha composición textural. Un resumen de las propiedades físicas de distintas variedades de la Piedra de Bateig comercializadas actualmente puede verse en 5 y 6 . La composición mineralógica de la Piedra Bateig, con un estudio detallado de los filosilicatos se muestra en 7. Todas las variedades de la Piedra Bateig son materiales porosos con porosidades de hasta el $12 \%$. Sus datos de porosidad están indicados en 6 y 8 .

En el conjunto de la calle Gravina se han utilizado dos variedades de dicha Piedra de Bateig en las reformas (Tabla 2); así encontramos materiales pétreos cuyas características se corresponden con las del denominado tipo Llano como el que aparece debajo de la ventana de Gravina 11. En general, cl material más utilizado en el aplacado de los sillares alterados se corresponde con las características del Bateig Blanco (Figura 6 f): biomicrita con rombos y otros clastos de dolomía y claro predominio de los foraminíferos dentro del conjunto de los fósiles presentes, constituido también por fragmentos de moluscos, de equinodermos y briozoos; contiene también cantidades variables de material argilomicáceo irregularmente distribuidas y presenta un macroporosidad this rock, oxide masses are also present. Its physical proprieties are shown in Table 2.

As a restoration material, a micrite with algae structures has also been used. This is abundant in bug porosity and bioturbations, possibly charophyte ghosts, and slight indications of aleuritic quartz.

The calcarenite of the San Julian type of Stone is not homogeneous since the one presumably used in the original, specially in the door post of Gravina 11, present petrographics features demonstrating variations with respect to the more characteristic features which can be observed in the abandoned fronts of the quarry: contain in the order of 20\% detritic (quartz, feldspar and a small quantity of silex) $5 \%$ glauconite and a similar percentage of dolomite; detritic minerals show a mode of 0,12-0,25 $\mathrm{mm}$ while the rest are slightly larger fossils (foraminifer and fragments of molluscs, echinoderms and bryozoans). In the paste, there is a clear predomination of micrite and inter and intraparticle porosity is abundant (Figure 6d).

In successive restoration processes, Bateig Stone has been used, especially for exterior claddings (Figure $6 f)$, since the San Julian Stone was not marketed until recently. Bateig Stone has different varieties, both in its mineralogical and textural composition. Its physical properties experience some variations according to this textural composition. A summary of the physical properties of the different varieties of the recently marketed Bateig Stone can be seen in 5 and 6. The mineralogical composition of Bateig Stone with a detailed study of phyllosilicates is shown in 7. All the varieties of the Bateig Stone are porous materials with porosity's of up to $12 \%$. Detailed porosity data are indicated in 6 and 8.

On the Gravina street unit, two varieties of the Bateig Stone have been used during the restoration processes (Table 2). Therefore, stone materials are found with characteristics of the Layer Bateig variety, similar to those used in the windowsills of $n^{\circ} 11$ Gravina Street. Generally, the most commonly used material on the weathered stone block covering is White Bateig, with the following characteristics (Figure $6 \mathrm{f}$ ): sandy biomicrite with rhombohedron and other dolostone clasts and a clear predomination of foraminifera within the fossil group. The stone is also made up of fragments of molluscs, echinoderms and bryozoans and contains varying quantities of irregularly distributed phyllosilicates, and both inter and intraparticle macroporosity prevail. Normally the phyllosilicates 
predominante de tipo intrapartícula. Habitualmente los filosilicatos representan menos de un $10 \%$ de la composición mineralógica total del Bateig Blanco y menos de un $15 \%$ de la del Bateig Llano. El Bateig Blanco contiene de un 3\% a un 6\% de micas y de un $1 \%$ a un $4 \%$ de esmectitas. El Bateig Llano de un $6 \%$ a un $10 \%$ de micas y $2 \%$ a $4 \%$ de esmectitas. El Bateig Blanco y el Bateig Llano muestran altos valores de mesoporosidad.

\section{Alteraciones en los materiales pétreos}

Las calcarenitas usadas en los exteriores de los Palacios Civiles y de otros edificios en la calle Gravina en Alicante están intensamente meteorizadas. El aplacado ha sido destruido y será reemplazado en los actuales procesos de restauración.

Las alteraciones presentes en los materiales pétreos situados en el exterior, emplazados hasta 1970, son fundamentalmente disgregación granular (arenización) y alveolizaciones.

La disgregación granular, se manifiesta principalmente en las zonas bajas e intermedias (hasta $2 \mathrm{~m}$ ). Los procesos de erosión alveolar están muy avanzados, concentrándose a alturas medias del orden de $1-1,2 \mathrm{~m}$.

Los procesos de desintegración granular están determinados por las características texturales de los materiales biocalcareníticos utilizados en los exteriores, tanto en la construcción como en la restauración.

En la Figura 7A puede observarse la desaparición del material intergrano (pasta), fase previa al desprendimiento de fósiles y granos detríticos o disgregación granular.

Estas alteraciones pueden considerarse como las primeras etapas, etapas 2 y 3 de procesos de alveolización (9). En la misma calle, en otros edificios más expuestos al viento marino y a la irradiación solar, encontramos alveolizaciones con etapas más avanzadas (fases 4 y 5 de los citados autores).

Al ser estas alteraciones especialmente intensas en las partes bajas de exteriores; en restauraciones anteriores se procedió al rechapado en los sillares más alterados utilizando Piedra de Bateig. Los aplacados más antiguos aparecen desprendidos (Figura 5) y en su cara interna hemos podido identificar por difracción de rayos X y microscopía electrónica de barrido la presencia de yeso, halita y ettringita (Figura 7B). phyllosilicates, and both inter and intraparticle macroporosity prevail. Normally the phyllosilicates represent less than 10\% of the total mineralogical composition of White Bateig and less than $15 \%$ of Llano Bateig. The White Bateig contain from 3 to $6 \%$ mica and from 1 to $4 \%$ smectite. The Llano Bateig contains from 6 to $10 \%$ mica and 2 to $4 \%$ smectite. Both the White Bateig and the Llano Bateig show high mesoporosity values.

\section{Stone material deterioration}

The calcarenites used on exterior of the Civil Palaces and other buildings in Gravina Street in Alicante are very weathered. The cladding has been destroyed and it will be replaced in the current restoration process.

The deterioration of the stone materials located on the exterior, building until 1970, was mainly granular disintegration (sanding) and alveolizations.

Granular disintegration is mainly placed in low and intermediate zones (until $2 \mathrm{~m}$ ). Alveolar weathering processes are advanced, its are concentrated in 1-1.2 m high.

Granular disintegration processes are determined by the textural characteristics of the biocalcarenitic materials used on the exterior so much in the construction as in the restoration.

In the Figure $7 A$, it is possible to observe the disappearance of intergrain material (paste), before fossil and detritic grain detachment.

This deterioration can be considered as the first stages, stages 2 and 3 as alveolar weathering (9). In the same street, on other buildings which are more exposed to the sea wind and to solar irradiation, alveolar weathering can be found at more advanced stages (stages 4 and 5 according to the aforementioned authors).

Outdoor weathering is especially intense on the low part as in previous restoration processes the most damaged stone blocks were covered with Bateig Stone. The older claddings are detached (Figure 5) and on the inner face, gypsum, halite and ettringite have been identified by X-ray diffraction and scanning electronic microscopy (Figure 7B). 

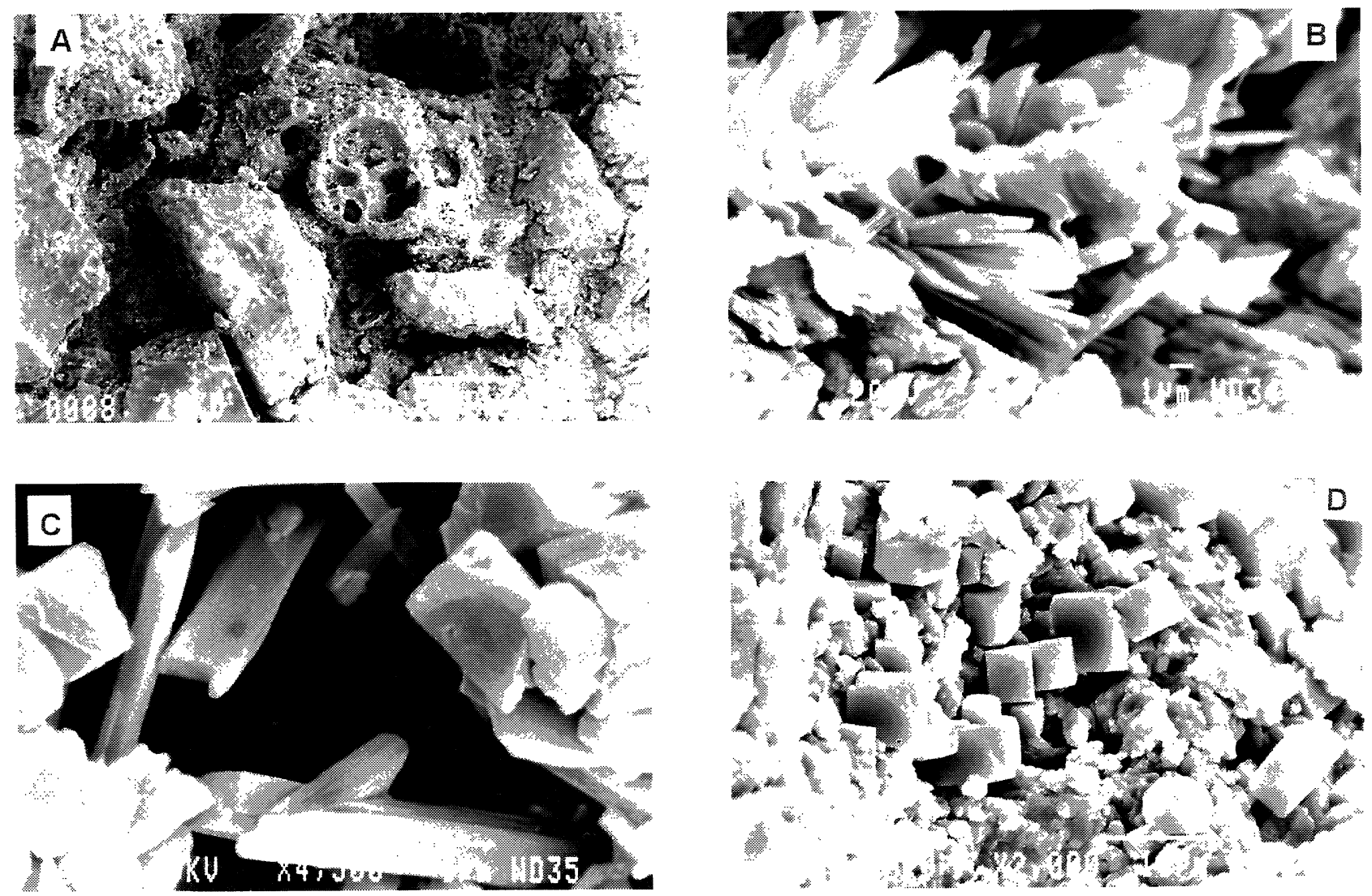

Figura 7.- Microfotografías con el MEB-ES de alteraciones: A) Disgregación granular de piedras del aplacado, B) Ettringita y halita de la cara interna del aplacado exterior, C) Eflorescencias de yeso y halita de la cara externa del aplacado exterior, D) Eflorescencias de halita del interior del Palacio de Gravina $\mathrm{n}^{\circ} 13$ (ver figura 4 ).

Figure 7.- SEM-SE microphotographs of alterations: A) Granular desintegration of cladding stone, B) Ettringite and gypsum in the inner face of cladding stone, C) Gypsum and halite efflorescence in the outer surface of cladding stone, D) Halite efflorescence indoor Palace Gravina $n^{\prime \prime} 13$ (see figure 4).

Las eflorescencias exteriores contienen yeso y halita (Figura 7C).

La halita no sólo está presente en eflorescencias de exteriores, también está presente en eflorescencias de interiores (Figura 7D). Pero las alteraciones en las calizas de interiores son escasas, presentándose sólo pequeñas descamaciones en las zonas con mayores cantidades de sal.

\section{DISCUSIÓN}

La disgregación granular, que tiene lugar como resultado de las características texturales de los materiales biocalcareníticos, constituye la ctapa inicial de la crosión alveolar. La textura de las rocas, principalmente la porosidad circungranular e interpartícula, desempeña el papel más importante en la disgregración granular del exterior de los edificios.
Outdoor efflorescences contain gypsum and halite (Figure 7C).

The halite is not only present in outdoor but also indoor efflorescences (Figure 7D). But the alterations in the inner limestones are scarse, only little desquamations or flakes are exhibit in the zones with large quantities of salts.

\section{DISCUSION}

Granular disintegration, which occurs as a result of the textural characteristics of the biocalcarenitic materials, is the initial stage of alveolar weathering. The stone texture, mainly circumgranular and interparticle porosity is the most important factor in granular disintegration outdoor the buildings. 
La cristalización de sales es el factor más determinante de la erosión alveolar. Los factores citados actúan sinérgicamente. Un solo factor y/o proceso no puede explicar la erosión alveolar estudiada. Esto está de acuerdo con las observaciones sobre la metcorización alveolar "tafoni" en la cuenca del Ebro (10) y en algunas areniscas de Nevada y Utah (11).

La metcorización alveolar está más avanzada en los edificios que están expuestos al viento marino $\left(n^{\circ} 15\right.$ y $\mathrm{n}^{0} 17$ de la calle Gravina). Esto es probablemente debido al hecho de que el viento favorece la cristalización de sales que se manifiestan como subeflorescencias destructivas y también aporta grandes cantidades de sal marina. Sin embargo, esta parte de la calle recibe más horas de exposición solar así que es posible que la alta irradiación solar influencie en la transferencia de humedad, evaporación y cristalización de sales, así como en el establecimiento e incremento de la frecuencia de ciclos de cristalización de sales.

Cuando la cavidad ha sido formada por disgregación granular, en primer lugar se produce la evaporación más rápidamente en la superficie inferior de las cavidades desarrolladas en la picdra. Además el punto de saturación se alcanza primero en dicha superficie y no en aquellas paredes que tienen un contenido inferior de cloruro sódico, como se ha demostrado experimentalmente (12).

El bajo contenido en agua juega un importante papel en la cristalización de sales: los cambios en la presión de cristalización controlados por la evolución de la salmucra contribuyen intensamente a la disgregación granular (13).

La acción mecánica de la presión de cristalización del cloruro sódico produce un incremento del número de canales y poros conectados en las rocas porosas (porosidad conectada). El deterioro de las rocas con más alta mesoporosidad es muy elevado porque la accesibilidad de las soluciones acuosas depende del tamaño de poro, lo que explica el intenso deterioro sufrido por las biocalcarenitas de los Palacios de la calle de Gravina. Este hecho ha sido probado experimentalmente y calculado matemáticamente (8).

La mayor intensidad de las alteraciones en las partes bajas y exteriores de los edificios puede cxplicarse por la suma del aporte de sales por el freático con el procedente del spray marino.

El yeso y la ettringita han contribuido al desprendimiento del aplacado realizado en restauraciones previas. El uso de morteros con tratamientos para climinar las sales solubles y la
Salt crystallisation is the most determinant factor in alveolar weathering. The aforementioned factors act synergistically. One single factor and/or process cannot explain the studied alveolar weathering. This is in keeping with the remarks about "tafoni" weathering in the Ebro basin (10) and in some sandstone in Nevada and Utah (11).

Alveolar weathering is more advanced on the buildings which are exposed to sea wind $\left(n^{\circ} 15\right.$ and 17, Gravina Street). This is probably due to the fact that this wind encourages salt crystallisation which manifests itself as destructive subefflorescence and also brings with it a large amount of sea salt. Moreover, this part of the street receives many hours of sunshine, thus it is possible that the high solar irradiation influences transfer via humidity, evaporation and salt crystallisation, as well as determining and increasing the frequency of salt crystallisation cycles.

When the cavity has been formed by granular disintegration, firstly, evaporation occurs more rapidly at the bottom of cavities developed on stone. Furthermore, saturation point is reached sooner at the bottom of the cavities and not within those walls which have a lower sodium chloride content as it has been experimentally proved (12)

The low water content, plays a very important role in salt crystallisation: the changes in crystallisation pressure controlled by brine evolution contribute greatly to granular disintegration (13).

The mechanical action of crystallisation pressure of sodium chloride produces an increase in the pore number and channels and connected pores in the porous stones (connected porosity). Damage to stones with the highest mesoporosity is very serious because of the water solution accessibility depends on pore size, which explain the intense deterioration suffered by the biocalcarenites of the Palaces of the Gravina street. This fact has been experimentally proved and mathematically calculated (8).

The greatest intensity of this alterations in the low and out part of buildings may be explain by the addition of salts approved by the freatic level and the marine spray.

Gypsum and ettringite have contributed to the detachment of claddings in previous restorations. The use of mortars with treatments for eliminating 
humedad en el aplacado (14) podrían prevenir su destrucción.

La presencia de halita en las eflorescencias de los interiores prueba que parte del cloruro sódico alcanzó el edificio por las aguas capilares del suelo.

No hay un deterioro significativo de las calizas del interior de los palacios a pesar de la presencia de halita. Este hecho es un cjemplo de la influencia que la textura de las rocas tiene en la intensidad y la morfología de las alteraciones ya que recordemos que cl material utilizado en interiores son calizas poco porosas. mientras que el utilizado en exteriores consiste en biocalcarenitas muy porosas. Un estudio del microambiente del interior scría necesario para definir los principales puntos de aportación de esta halita y así prevenir la formación de eflorescencias.

\section{AGRADECIMIENTOS}

Este estudio ha sido parcialmente financiado por la DGES (Proyecto de Investigación PB96-0321). soluble salts and damp in the cladding (14) could prevent the destruction of the cladding.

The presence of halite in indoor efflorescence proves that $\mathrm{NaCl}$ has possibly reached the building via soil capillary waters.

There are no significant damage to the limestone within the palaces in spite of the presence of halite. This fact is an example of the influence that the texture of the stones has in the intensity of the morphology of the alterations, remembering that the material utilized in the interiors are limestones with low porosities while that used on the exteriors consists of biocalcarenites which are very porous. An indoor micro-environment monitoring study will be needed in order to discover the main points of contribution of this halite and thus prevent the formation of efflorecences.

\section{ACKNOWLEDGEMENTS}

This study was partially supported by DGES of Spain (Research Project PB96-0321).

\section{BIBLIOGRAFÍA}

(1) M. Beviá, S. Varela: Alicante ciudad y arquitectura, p. 242, Fundación cultural CAM. Alicante. 1994.

(2) M. Louis, J. Alonso, L. A. Alonso., V. Galvañ: Characteristics, forms and mechanism or weathering of the stone caused by the salt spray in the stone used in the main monuments of the city of Alicante, Spain. In F. Zezza, ed. 1 ${ }^{\text {st }}$ Int. Symposium "The conservation of monuments in the Mediterranean Basin", Bari (1989), Ed. Grafo, Brescia, Italia. pp. 91-96.

(3) M. Louis, J. Alonso, L.A. Alonso, V. Galvañ: Geographic, climatic and environmental factors which influence the mechanisms of weathering of stone used in the main Monuments of the City of Alicante, Spain. European Symposium. Science, Technology and European Cultural Heritage. Commission of the European Communitics, Oxford(1991).pp. 388-392.

(4) M. Louis: El material pétreo utilizado en la construcción del Ayuntamiento de Alicante. Su alteración y tratamientos. VIII Congrés de conservació de béns culturals. Ed. Universidad Politécnica de Valencia. Consellería de Cultura, Educació i Ciencia. Generalitat Valenciana. Valencia(1990). pp.426-438.

(5) M. Louis: Caractéristiques minéralogiques, pétrophysiques et pétrochimiques du gres naturel de Bateig (Alicante) fréquemment utilisé dans l'architecture espagnole. 7th International Congress on Deterioration and Conservation of Stone. Lisboa, 15-18 (1992). Ed: Laboratório Nacional de Engenharia Civil, LNEC, Vol.3,pp. 1205-1211.

(6) S. Ordóñez, M.A. García del Cura, R. Fort, M. Louis, M.C. Lopez de Azcona, F. Mingarro: Physical properties and petrographic characteristics of some Bateig stone varieties. $7^{\text {th }}$ Int IAEG Congress. Lisboa (1994). Vol. 5. Ed. Balkema. Rotterdam. pp $3595-3603$.

(7) A. La Iglesia, M.A. García del Cura, S. Ordóñez, A. Bernabéu: Estudio de los filosilicatos de la Piedra Bateig (Neógeno de la provincia de Alicante). Geogaceta. Vol 23, (1998), p. 79-82.

(8) D. Benavente, M.A. García del Cura, R. Fort, S. Ordóñez: Thermodynamic modelling of changes induced by salt pressure crystallization in porous media of stone. Journal of Crystal Growth, Vol. 204, $\mathrm{n}^{\circ} 1-2$ (1999), pp.168-178.

(9) B. Fitzner, K. Heinrichs, M. Volker: Model for salt wathering at maltese globerina limestones. In F. Zezza, F. Ed. "Origin, mechanisms and effects of salts on degradation of monuments in marine and continental environments". Research Workshop. Bari (1996), pp. 333 - 344. (10) C. Sancho, G. Benito: Factors controlling tafoni weathering in the Ebro Basin (NE Spain). Z. Geomorph. N.F. Vol. 34, (1990) pp. 165-177.

(11) A.V. Turkington: Cavernous weathering in sandstone: lessons to be learned from natural exposures. Quarterly Journal of Engineering Geology, Vol 31, $\mathrm{n}^{\circ} 4$ (1998),pp 375-384.

(12) C. Rodriguez Navarro, E. Doehne, E. Sebastián: Origins of honeycomb weathering: the role of salts and wind. GSA Bulletin, Vol. 111 (1999), pp. $1250-1255$.

(13) A. La Iglesia, M. A. García del Cura, S. Ordóñez: The physicochemical weathering of monumental dolostones, granites and limestones; dimension stones of the Cathedral of Toledo (Spain): The Science of the Total Environment, Vol. 152 (1994), pp. 179-188. (14) M. Louis, Y. Spairani, S. Chinchón: Study of the treatments for the elimination of soluble salts and dampness in the repair of coating stone buildings. In: A. Moropoulou, F. Zezza, E. Kollias, I. Papachristodoulou, I. Eds. $4{ }^{\text {th }}$ Int. Symposium on the Conservation of Monuments in the Mediterranean. Rhodas, (1997). Vol. 3. Technical Chamber of Greece. Athens. pp. 177-191 